\title{
A diabeteses neuropathia és egyéb szövődmények előfordulása a Debreceni Egyetem Diabeteses Neuropathia Centrumában
}

\author{
Sztanek Ferenc dr. - Balogh Bernadett dr. \\ Molnár Ágnes dr. - Zöld Eszter dr. - Tóth Nóra dr. \\ Jakab András Áron dr. - Paragh György dr.
}

Debreceni Egyetem, Általános Orvostudományi Kar, Anyagcsere Betegségek Nem Önálló Tanszék, Belgyógyászati Intézet, Debrecen

\begin{abstract}
Bevezetés: Világszerte jelentősen növekszik a cukorbetegség előfordulása. A distalis típusú szenzomotoros polyneuropathia (DSPN) a leggyakrabban előforduló és a legkorábban kimutatható microvascularis szövődmény, mely változatos klinikai megjelenése és sokszor atípusos tünetei miatt gyakran csak a cukorbetegség elörehaladott stádiumában kerül felismerésre.

Célkituzésés módszer: Munkánk során 431 beteg adatait dolgoztuk fel, akiket 2011 és 2018 között a Debreceni Egyetem Diabeteses Neuropathia Centrumában vizsgáltunk Neurometer ${ }^{\circledR}$ segítségével, és összefüggéseket kerestünk a különböző szív-ér rendszeri és microvascularis szövődmények (retinopathia, microalbuminuria), a laboratóriumi paraméterek és a DSPN súlyossága között.

Eredmények: A betegek átlagéletkora 63,4 év, 62\%-uk nő volt, 92\%-uk 2-es típusú cukorbetegségben szenvedett. A cukorbetegség fennállásának átlagos ideje 13,7 év volt. Cardiovascularis betegség a betegek 42\%-ánál volt ismert. A microvascularis szövődmények közül a retinopathia előfordulása $12 \%$ volt, perzisztáló microalbuminuria a betegek 16\%-ánál volt igazolva. A vizsgált betegek 19\%-ánál a típusos DSPN-panaszok ellenére sem tudtunk idegi károsodást kimutatni; 49\%-ban enyhe fokú, 19\%-ban közepes fokú és 13\%-ban súlyos fokú neuropathia volt kimutatható Neurometer $^{\circledR}$ segítségével. A cukorbetegséggel összefüggő idegi károsodás kifejezettebb volt diabeteses retinopathia $(\mathrm{p}<0,001)$ és perzisztáló microalbuminuria esetén $(\mathrm{p}<0,001)$, e microvascularis szövődmények előfordulása összefüggést mutatott a DSPN súlyosságával. A cardiovascularis szövődmények megjelenése nem mutatott korrelációt a perifériás idegkárosodás mértékével, és nem találtunk összefüggést a DSPN súlyossági foka és a cardiovascularis betegségek előfordulása között.

Következtetés: Eredményeink alapján a diabeteses neuropathia progressziója elöre jelezheti az egyéb microvascularis szövődmények megjelenését 2-es típusú cukorbetegségben, adataink azonban nem mutattak összefüggést a cardiovascularis betegségek kialakulásával. A Neurometer ${ }^{\circledR}$ segítségével végzett perifériás idegrendszeri vizsgálat alkalmas a DSPN követésére és a neuropathia súlyosságának megállapítására. A cardiovascularis kockázatot az autonóm idegrendszeri funkciót vizsgáló Ewing-féle reflextesztek segítségével jobban meg tudjuk ítélni cukorbetegeinknél.
\end{abstract} Orv Hetil. 2020; 161(30): 1243-1251.

Kulcsszavak: cukorbetegség, diabeteses neuropathia, cardiovascularis szövődmények, microvascularis szövődmények

\section{Diabetic neuropathy and other diabetic complications at the Diabetic Neuropathy Center of the University of Debrecen}

Introduction: The prevalence of diabetes mellitus is significantly increasing worldwide. Distal sensorimotor neuropathy (DSPN) is the most common and the earliest detectable microvascular complication. Due to its diverse clinical appearance and atypical symptoms, DSPN is often recognized in an advanced stage.

Aim and method: In our study, the data of 431 patients who were examined using the Neurometer ${ }^{\circledR}$ between 2011 and 2018 at the Diabetic Neuropathy Center of the University of Debrecen were processed and the correlations between cardiovascular and microvascular complications, laboratory parameters and the severity of DSPN were investigated. 
Results: The average age of patients was 63.4 years, $62 \%$ of them were women, and $92 \%$ had type 2 diabetes mellitus. The average duration of diabetes was 13.7 years. Cardiovascular disease (CVD) was diagnosed in $42 \%$ of the patients. The incidence of retinopathy was $12 \%$, persistent microalbuminuria was $16 \%$. Despite DSNP complaints, neuronal damage could not be detected in 19\%; in the examined patients $49 \%$ had mild, $19 \%$ moderate and $13 \%$ severe neuropathy. Diabetes-related neurological damage was more serious in the presence of both diabetic retinopathy $(\mathrm{p}<0.001)$ and microalbuminuria $(\mathrm{p}<0.001)$. The incidence of these microvascular complications and the severity of DSPN showed a significant positive correlation $(\mathrm{p}<0.001)$. There was no correlation between the severity of peripheral neuropathy and the development of CVD, and we did not find any correlations between the severity of DSPN and CVD.

Conclusion: Based on our investigation, correlation between the progression of diabetic neuropathy and cardiovascular complications was not found, although the progression of diabetic neuropathy indicated the development of other microvascular diseases. Peripheral neurological examination using the Neurometer ${ }^{\circledR}$ is appropriate for controlling the DSPN status and the establishment of the severity of neuropathy determines the quality of life in diabetic patients. Among these patients, the risk of CVD can be assessed by Ewing's test for autonomic nervous system function.

Keywords: diabetes mellitus, diabetic neuropathy, cardiovascular complications, microvasular complications

Sztanek F, Balogh B, Molnár Á, Zöld E, Tóth N, Jakab AÁ, Paragh Gy. [Diabetic neuropathy and other diabetic complications at the Diabetic Neuropathy Center of the University of Debrecen]. Orv Hetil. 2020; 161(30): 12431251

(Beérkezett: 2020. március 20.; elfogadva: 2020. április 6.)

\section{Rövidítések}

ATP = adenozil-trifoszfát; $\mathrm{BNO}=$ betegségek nemzetközi osztályozása $\mathrm{CV}=$ cardiovascularis $; \mathrm{CVD}=($ cardiovascular disease) cardiovascularis betegség; DNS = dezoxiribonukleinsav; DSPN $=($ distal sensorimotor neuropathy $)$ distalis típusú szenzomotoros polyneuropathia; eGFR = (estimated glomerular filtration rate) becsült glomerulusfiltrációs ráta; $\mathrm{HbA}_{\mathrm{lc}}=$ hemoglobin- $A_{l c} ; \mathrm{HDL}=$ (high-density lipoprotein) magas sürüségű lipoprotein; $\mathrm{SD}=$ standard deviáció; $\mathrm{T} 2 \mathrm{DM}=($ type 2 diabetes mellitus) 2 -es típusú cukorbetegség; USA = (United States of America) Amerikai Egyesült Államok

A diabetes mellitus előfordulása világszerte jelentősen emelkedik, 2018-ban a 2-es típusú cukorbetegségben (T2DM) szenvedő betegek arányát a felnőtt lakosság 8,8\%-ára, számát mintegy 500 millióra becsülték; a prevalencia a fejlett és a fejlődő országokban egyaránt emelkedik [1]. A betegek körülbelül 77\%-a 20-64 éves, a munkaképes korosztályba tartozik, tehát jelentős a gazdasági és társadalmi jelentősége egyaránt. Az előrejelzések szerint 2045-re az idős betegpopuláció aránya is megduplázódik [2]. Magyarországon a cukorbetegség prevalenciája $6,4 \%$ körüli, amely az utóbbi években stagnáló tendenciával, az életkor elórehaladtával azonban fokozatosan növekszik [3]. A betegek több mint 90\%-a T2DM-ben szenved.

A distalis típusú szenzomotoros polyneuropathia (DSPN) prevalenciája Európában T2DM esetében 1835\% között mozog [4]. A DSPN változatos klinikai megjelenése és sokszor nem típusos tünetei miatt sok esetben nem valósulhat meg a korai diagnózis, ami a megfelelő oki és tüneti kezelés elkezdése szempontjából kiemelkedő fontosságú lenne [5]. A leggyakrabban a vas- tag és vékony szenzoros idegrostok károsodása fordul elő DSPN-ben a tapintás-, az egyensúly- és hőérzés zavarát okozva. Az időben történő felismerés, a specifikus terápia és a megelőző lábápolás jelentősen csökkenti az érzéskiesésből adódó lábsérülések és a diabeteses lábfekélyek kialakulásának kockázatát. Továbbá az autonóm neuropathia felismerése és kezelése csökkenti a cardiovascularis kockázatot, és javítja az életminőséget [6]. Korábban igazolódott, hogy a DSPN a cardiovascularis esemény bekövetkezésének független prediktora [7], valamint szoros összefüggést mutat az egyéb microvascularis szövődményekkel, a diabeteses retinopathia és a microalbuminuria fennállásával [8].

A DSPN leggyakoribb endogén metabolikus oka a cukorbetegség, kialakulásának pontos mechanizmusa azonban jelenleg sem ismert. Kialakulását két fó tényező idézi elő: az idegszövet vérellátásáért felelős vasa nervorum károsodása és a sejtanyagcsere kóros változásainak hatása. Az érfali károsodások többféle mechanizmus révén jöhetnek létre. Az intracelluláris glükóztartalom megnövekedése fokozza a mitokondriumok szuperoxid-anionjainak termelését, felgyorsítja a glikolízis folyamatát, növeli a szabad gyökök képződését, továbbá felerősíti a gyulladásos folyamatokat [9]. A hyperglykaemia fokozza a fehérjék nem enzimatikus glikolizációját, aminek következménye az előrehaladott glikációs végtermékek felszaporodása, az endothelium diszfunkciója, fokozódik a vasoconstrictor anyagok (például endotelin, angiotenzin) felszabadulása, a vasodilatatiót kiváltó faktorok (például prosztaciklin, bradikinin) aránya csökken [10]. Különböző kóros szignálútvonalak aktivációja fokozza a proinflammatorikus citokinek termelődését és az apoptózis indukcióját. Az endoneuralis vérátáramlás csökke- 
nése, az idegszövet integritásának megbomlása és a javító (repair) mechanizmusok is károsodnak [11]. A reaktívoxigén-gyökök termelődése fokozódik, a szuperoxidion és a hidrogén-peroxid közvetlenül károsítják a fehérjéket és a mitokondriális DNS-t is, valamint az ATP termelése is gátlás alá kerül. A mitokondriális károsodás következménye a csökkent neurotróf anyagok termelödése is [12]. A reaktív gyökök, többek között a szuperoxid-anion és peroxinitrit termelődése központi szerepet játszik az oxidatív stressz fokozódásában, a nitrogén-monoxid termelődése csökken, károsodik az endothel funkciója és az idegszövet véráramlása [13]. A tartósan magas vércukorszint következtében a neuronokban a glikolízis folyamata telítődik, és alternatív anyagcsere-útvonalak, többek között a poliolútvonal aktiválódik, melynek során szorbitol és a belőle keletkező fruktóz felhalmozódik. Mivel a sejtmembrán átjárhatatlan a szorbitol számára, nő az ozmotikus nyomás, aminek következtében végső soron az axonális transzport és a strukturális fehérjék is károsodhatnak [14]. A hexózamin-útvonal is alternatív glükózlebontási folyamatnak felel meg, ennek során végül $\mathrm{N}$-acetil-glükózamin keletkezik, mely transzkripciós faktorok oldalláncaihoz kapcsolódva citokintermelődést és apoptózist indukál [15].

A diabeteses neuropathia a legtöbbször jellegzetes klinikai képpel rendelkezik, azonban atípusos tünetek esetén nehezített lehet a diagnózis felállítása. A DSPN-re jellemző panaszok a szimmetrikus, gyakran az alsó és felső végtagokat érintő, harisnya-, illetve kesztyüujj formájában fennálló bizsergés vagy tûszúrásszerü fájdalom. A betegek jellegzetesen éjszaka és nyugalomban a tünetek súlyosbodását panaszolják. Az alsó végtagi reflexek renyhesége vagy kiesése is szembetűnő lehet. Az idegrendszeri és társuló microangiopathiás károsodások következménye a diabetesesláb-szindróma kialakulása, mely a DSPN legrettegettebb szövődménye: a beteg nem érzékeli a lábán keletkező sérüléseket, mély fekélyek alakulhatnak ki rossz gyógyulási hajlammal és az amputáció veszélyével. A DSPN következtében a láb szerkezete is megváltozhat, ún. Charcot-féle neuropathiás osteoarthropathia alakulhat ki [16].

A cukorbetegek szűrése DSPN irányában a legtöbbször a háziorvosi rendelőkben, diabetes-szakrendeléseken és belgyógyászati osztályokon zajlik, részletes kivizsgálás azonban Magyarországon a regionális diabeteses neuropathia centrumokban történik [16]. A vibrációérzést a Rydel-Seiffer-féle, $128 \mathrm{~Hz}$-es kalibrált hangvilla segítségével vizsgálhatjuk, a nyomásérzés vizsgálatára a 10 grammos Semmes-Weinstein-féle mikrofilamentumtesztet alkalmazzuk, így a vastag mielinizált idegrostok állapota ítélhető meg. Lehetőségünk van Neurotips ${ }^{{ }_{1}}$ vizsgálatra, melynek során steril múanyag túvel enyhe nyomást gyakorolunk a beteg talpára, s egészséges esetben fájdalomérzetet váltunk ki. A kóros sudomotoros funkciót a Neuropad ${ }^{\circledR}$ segítségével tudjuk igazolni. Az elektroneurográfiás vizsgálat a leginkább differenciáldiagnosztikai szempontból jelentős, és a legtöbbször nem szükséges a diabeteses neuropathia diagnózisának felállításához. A magyarországi diabeteses neuropathia centrumokban a Neurometer $^{\circledR}$ (Neurotron Inc., Baltimore, MD, USA, 2002) segítségével kvantitatívan tudjuk vizsgálni az áramérzet-küszöbérték kóros változásait. A vizsgálat során a nervus medianust és a nervus peroneus superficialist ellenőrizzük különböző áramerősségekkel (0,01-0,99 mA) többször ismételve, három különböző frekvencián. $2000 \mathrm{~Hz}$-en a vastag mielinizált rostokat, $250 \mathrm{~Hz}$-en a vékony mielinizált rostokat, még $5 \mathrm{~Hz}$-en a vékony mielinizálatlan rostokat ingereljük, majd a beteg áramérzet-küszöbértéke alapján határozzuk meg az idegi károsodás mértékét. Minél magasabb a páciens áramérzet-küszöbértéke, annál súlyosabb neuropathiát valószínűsíthetünk. A vizsgálat nemcsak a DSPN szürésére, hanem a betegség követésére is alkalmazható [16]. A diagnózis felállításához együtt kell értékelnünk a betegek klinikai tüneteit, szénhidrátháztartását és az eszközös vizsgálatok során kapott eredményeket. A cardiovascularis autonóm neuropathia kimutatása a Ewing-féle cardiovascularis reflextesztek elvégzésével történik. A paraszimpatikus funkciót a mélybelégzés-teszttel, a Valsalvahányadossal és a felállás okozta szívfrekvencia-változás segítségével vizsgáljuk. A szimpatikus idegrendszer müködését a felállás során mért szisztolés vérnyomáscsökkenéssel, illetve a kézszorítási teszt során mért diasztolés vérnyomás-emelkedés megállapításával határozhatjuk meg. A cardiovascularis autonóm neuropathia jelenléte T2DM-ben a szív- és érrendszeri betegségek előfordulásának kockázati tényezője, ezért korai diagnosztikája jelentős szerepet játszhat a fó cardiovascularis események, mint a szívizominfarktus, a stroke és a szívelégtelenség megelőzése szempontjából [17].

Munkánk során a Diabeteses Neuropathia Centrumunkban vizsgálaton megjelenő cukorbetegek adatait gyưjtöttük össze, és DSPN jelenlétében kerestük a micro- és macrovascularis szövődményeket, a kóros laborparaméterek és az egyéb kockázati tényezók összefüggéseit. Vizsgálatunkkal hangsúlyozni kívánjuk a DSPN korai felismerésének és kezelésének fontosságát cukorbetegeink körében.

\section{Betegek és módszer}

Vizsgálatunkba olyan, korábban igazolt cukorbetegeket választottunk be, akik 2011 és 2018 között a Debreceni Egyetem Diabeteses Neuropathia Centrumában neuropathiás szúrővizsgálaton estek át, és akiknek a dokumentációjában (a MedSolution rendszer adatbázisa és a Neuropathia Centrum regisztere alapján) rendelkezésünkre álltak információk a macro- és microvascularis szövődmények jelenlétéról vagy hiányáról, az egyéb vizsgált rizikófaktorokkal (dohányzás, alkoholfogyasztás, hypertonia) és laborparaméterekkel együtt. Kizártuk azon betegeket, akiknek igazoltan más etiológiájú, nem diabeteses neuropathiájuk volt, vagy az előbb említett adatok nem álltak rendelkezésünkre. Kizáró tényezőink közé 
tartozott a kóros alkoholfogyasztás, az alkohol indukálta májkárosodás és az egyéb eredetű hepatopathia, melyeket az anamnézis és a májfunkciós értékek alapján állapítottunk meg. A Neurometer ${ }^{\circledR}$ segítségével meghatározott áramérzet-küszöbértékek mindkét lábon és mindhárom neuronalis rosttípusra vonatkozó átlagát használtuk fel a statisztikai számítások során. Vizsgálatunk során SAS for Windows 6.12 (SAS Institute Inc., Cary, NC, USA) számítógépes programot használtunk statisztikai analízis céljából. Az adatok normáleloszlását, ezáltal az összehasonlíthatóságukat Kolmogorov-Szmirnov-teszttel ellenőriztük. A normális eloszlást mutató paramétereknél az adatokat átlagérték \pm szórás (SD) formában, nem normális eloszlás esetén medián és alsó-felső kvartilisek megadásával ábrázoltuk. A különböző csoportok összehasonlítása során normális eloszlás esetén kétmintás t-próbát (Student-féle t-teszt), a nem normális eloszlást mutató paramétereknél pedig Mann-Whitneypróbát alkalmaztunk; szignifikánsnak tekintettük a $\mathrm{p}<0,05$ értéket. A nem normális eloszlású változók 10-es alapú logaritmusát véve végeztünk lineáris regressziós analízist. Minőségi változók esetén khi-négyzet-szignifikanciatesztet alkalmaztunk.

\section{Eredmények}

Vizsgálatunkba 431 beteget vontunk be, akiknek antropometriai adatait és laboratóriumi eredményeit az 1. táblázatban foglaltuk össze. A betegek több mint 90\%-a

1. táblázat A diabeteses neuropathiás betegek antropometriai és laborparaméterei

\begin{tabular}{|c|c|}
\hline Paraméterek & Átlag \pm SD $/$ Medián (kvartilisek) \\
\hline Betegszám (fő) & 431 \\
\hline T1DM/T2DM (fö) & $36 / 395$ \\
\hline Férfi/nő (fö) & $164 / 267$ \\
\hline Életkor (év) & $63,39 \pm 10,99$ \\
\hline Diabetes fennállása (év) & $13,74 \pm 9,81$ \\
\hline Neurometer $^{\circledR}$-átlag $(\mathrm{mA})$ & $304,02(213,83-337,17)$ \\
\hline sTSH $(\mathrm{mIU} / \mathrm{l})$ & $2,35(1,07-2,80)$ \\
\hline D-vitamin $(\mathrm{nmol} / \mathrm{l})$ & $64,20 \pm 28,66$ \\
\hline Hemoglobin $(\mathrm{g} / \mathrm{l})$ & $133,65(125,00-144,00)$ \\
\hline $\mathrm{HbA}_{\mathrm{lc}}(\%)$ & $7,44(6,3-8,3)$ \\
\hline $\operatorname{eGFR}\left(\mathrm{ml} / \operatorname{perc} / 1,73 \mathrm{~m}^{2}\right)$ & $73,84 \pm 19,41$ \\
\hline Triglicerid (mmol/l) & $2,06(1,10-2,40)$ \\
\hline Koleszterin $(\mathrm{mmol} / \mathrm{l})$ & $4,97(3,90-5,70)$ \\
\hline HDL-koleszterin (mmol/l) & $1,33(1,00-1,60)$ \\
\hline LDL-koleszterin (mmol/l) & $2,85(2,00-3,60)$ \\
\hline
\end{tabular}

eGFR = becsült glomerulusfiltrációs ráta; $\mathrm{HbA}_{\mathrm{lc}}=$ hemoglobin- $\mathrm{A}_{\mathrm{lc}}$; $\mathrm{HDL}=$ magas sûrűségű lipoprotein; $\mathrm{LDL}=$ alacsony sűrüségú lipoprotein; $\mathrm{SD}=$ standard deviáció; sTSH = szenzitív thyreoideastimuláló hormon; T1DM = 1-es típusú cukorbetegség; T2DM = 2-es típusú cukorbetegség

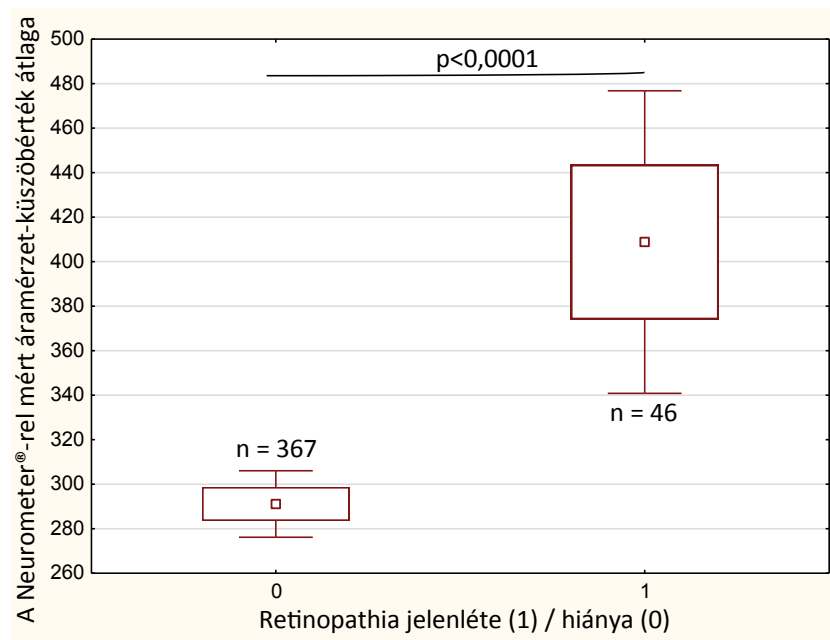

1. ábra $\quad$ A diabeteses neuropathia súlyossága (az áramérzet-küszöbérték alapján) a retinopathiás szövődmény jelenléte esetén
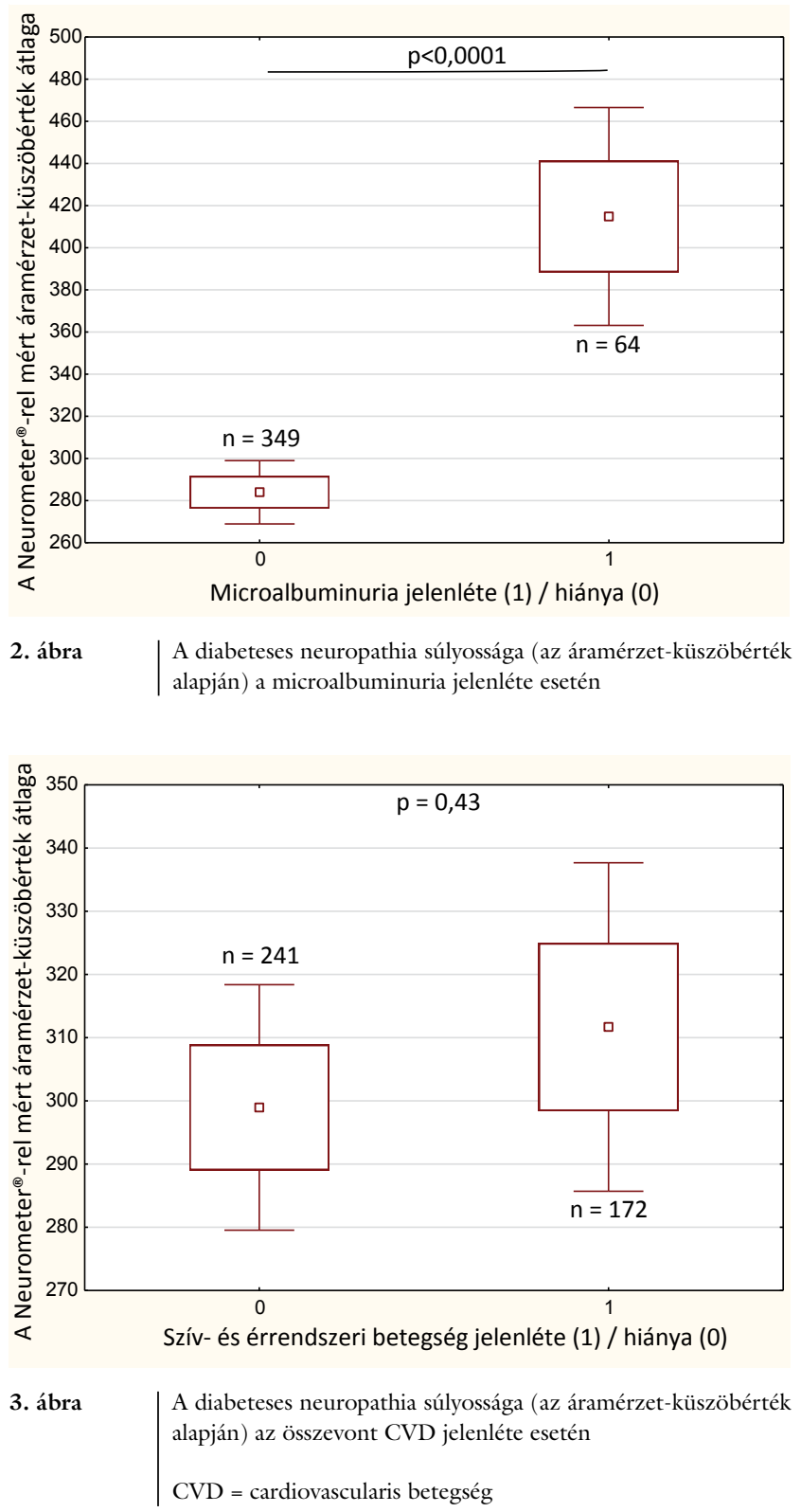
2. táblázat |A CV-betegségben szenvedő és azoktól mentes alcsoportok összehasonlítása

\begin{tabular}{lccc}
\hline Változók & Nem igazolt CVD jelenléte & Igazolt CVD jelenléte & p-érték \\
\hline Életkor $($ év) & $64,12 \pm 7,35$ & $65,26 \pm 6,98$ & 0,23 \\
\hline Neurometer ${ }^{\circledR}$-átlag $(\mathrm{mA})$ & $266,17(214,00-332,83)$ & $263,00(212,92-342,08)$ & 0,60 \\
\hline Diabetes fennállása $($ év) & $12,00 \pm 4$ & $12,00 \pm 4,5$ & 0,57 \\
\hline sTSH $(\mathrm{mIU} / \mathrm{l})$ & $1,72(1,13-2,96)$ & $1,57(0,97-2,60)$ & 0,14 \\
\hline D-vitamin $(\mathrm{nmol} / \mathrm{l})$ & $57,60 \pm 13,20$ & $58,20 \pm 12,40$ & 0,94 \\
\hline Hemoglobin $(\mathrm{g} / \mathrm{l})$ & $136,00(127,00-145,00)$ & $132,50(123,00-143,00)$ & 0,13 \\
\hline HbA $_{1 \mathrm{c}}(\%)$ & $7,20(6,30-8,20)$ & $7,10(6,35-8,35)$ & 0,52 \\
\hline eGFR $\left(\mathrm{ml} /\right.$ perc/l,73 m $\left.{ }^{2}\right)$ & $83,50 \pm 6,30$ & $76,00 \pm 7,20$ & 0,03 \\
\hline Triglicerid $(\mathrm{mmol} / \mathrm{l})$ & $1,40(1,00-2,30)$ & $1,80(1,30-2,70)$ & 0,001 \\
\hline Koleszterin $(\mathrm{mmol} / \mathrm{l})$ & $4,65(4,00-5,70)$ & $4,60(3,80-5,70)$ & 0,85 \\
\hline HDL-koleszterin $(\mathrm{mmol} / \mathrm{l})$ & $1,30(1,10-1,60)$ & $1,20(0,90-1,50)$ & 0,003 \\
\hline LDL-koleszterin $(\mathrm{mmol} / \mathrm{l})$ & $2,70(2,00-3,60)$ & $2,74(2,00-3,60)$ & 0,65 \\
\hline
\end{tabular}

$\mathrm{CV}=$ cardiovascularis $; \mathrm{CVD}=$ cardiovascularis betegség; $\mathrm{eGFR}=$ becsült glomerulusfiltrációs ráta $; \mathrm{HbA}_{\mathrm{lc}}=$ hemoglobin- $\mathrm{A}_{\mathrm{lc}} ; \mathrm{HDL}=$ magas sűrúségú lipoprotein; $\mathrm{LDL}$ = alacsony sưrúségú lipoprotein; sTSH = szenzitív thyreoideastimuláló hormon

( $\mathrm{n}=395)$ T2DM-ben szenvedett. A vizsgált kohorsz 62\%-át nók alkották. A betegek átlagéletkora 63,4 év, a betegek átlagos $\mathrm{HbA}_{\mathrm{lc}}$-értéke 7,4\% volt. A rendelkezésünkre álló dokumentáció alapján igazolt macrovascularis szövődmény 183 betegnél, vagyis a kohorsz 42\%-ánál volt jelen. Microvascularis szövődményt (diabeteses retinopathia, microalbuminuria) a betegek 28\%-ánál találtunk, ami a vizsgálatban 119 fót jelentett. A Neurometer ${ }^{\circledR}$ vizsgálattal alátámasztott diabeteses neuropathiás páciensek száma 350 volt, ami a kohorsz 81\%-át tette ki. A betegek 19\%-ánál ( 81 fó) a típusos neuropathiás tünetek ellenére nem tudtunk elváltozást kimutatni a Neurometer $^{\circledR}$-vizsgálat alapján, ők feltehetően vékonyrost-neuropathiában szenvedtek.

Az 1. ábrán a Neurometer ${ }^{\circledR}$ segítségével meghatározott áramérzet-küszöbértéket, azaz a fennálló neuropathia súlyosságát hasonlítottuk a diabeteses retinopathia fennállásához. Ezen az ábrán látható, hogy a retinopathiás betegeknél szignifikánsan magasabb volt az áramérzet-küszöbérték átlagértéke $(\mathrm{p}<0,0001)$, tehát súlyosabb neuropathia véleményezhető.

Vizsgálatunk során a neuropathia súlyossága és a microalbuminuria közötti összefüggést is elemeztük: a retinopathiás esetekhez hasonlóan perzisztáló microalbuminuria esetén szignifikánsan magasabb áramérzet-küszöbértéket $(\mathrm{p}<0,0001)$, azaz előrehaladottabb neuropathiás idegkárosodást találtunk (2. ábra).

A cardiovascularis betegségeket mint összevont végpontot kezeltük vizsgálatunk során, idetartozik a kórelőzményben szereplő stabil angina pectoris, instabil angina pectoris, akut myocardialis infarctus, ischaemiás szívbetegség, igazolt szisztolés vagy diasztolés szívelégtelenség, előrehaladott balkamra-hypertrophia, átmeneti agyi ischaemia, stroke, perifériás alsó végtagi érszúlkület és hasiaorta-aneurysma. Az összevont CVD esetében nem igazolódott az áramérzet-küszöbérték tekintetében szignifikáns különbség a CVD-szövődménytől mentes betegeinkkel összehasonlítva (3. ábra).

Összehasonlítottuk a CVD-szövődményekkel rendelkező cukorbetegeket a szövődményektől mentes betegekkel, az eredményeket a 2. táblázatban foglaltuk öszsze. A CVD-szövődménnyel rendelkező alcsoportban a szérumtriglicerid-szint szignifikánsan magasabbnak, a HDL-koleszterin és az eGFR-érték szignifikánsan alacsonyabbnak bizonyult.

Lineáris regressziós analízist alkalmazva hasonlítottuk össze a különböző változók és a Neurometer ${ }^{\circledR}$ segítségével meghatározott áramérzet-küszöbérték átlagával jellemzett neuropathiás károsodás súlyosságát. A $\mathrm{HbA}_{\mathrm{lc}}$ pozitív korrelációt mutatott a DSPN súlyosságával $(\mathrm{r}=$ $0,1981, \mathrm{p}<0,001 ; 4$ ábra).

A különböző CV-rizikófaktorok és microvascularis szövődmények összehasonlításához a betegek tünetei és a Neurometer ${ }^{\circledR}$ segítségével meghatározott áramérzetküszöbérték szerinti DSPN súlyossága alapján a betegeket négy különböző csoportba soroltuk. Az első csoportban Neurometer ${ }^{\circledR}$-rel nem volt kimutatható az áramérzet-küszöbérték kóros változása (vékonyrost-neuropathia), a második csoportba az enyhe fokú, a harmadikba a mérsékelten súlyos és a negyedikbe a súlyos fokú DSPN-betegek kerültek. A kategorizálás után az adatokat khi-négyzet-szignifikanciatesztekkel vizsgáltuk. Az első diagramon a férfi-nő megoszlást ábrázoltuk; férfidominancia figyelhető meg a neuropathia súlyosbodásával $(\mathrm{p}<0,05 ; 5$. ábra $)$.

Az inzulinnal kezelt cukorbetegek száma szignifikánsan emelkedett a neuropathia súlyosságának függvényében $(\mathrm{p}<0,01 ; 6$. ábra).

A CV-rizikófaktorok közül a dohányzás, az alkoholfogyasztás nem mutatott szignifikáns eltérést a DSPN súlyossága alapján történt összehasonlítások során. A microvascularis szövődmények szempontjából mind a 


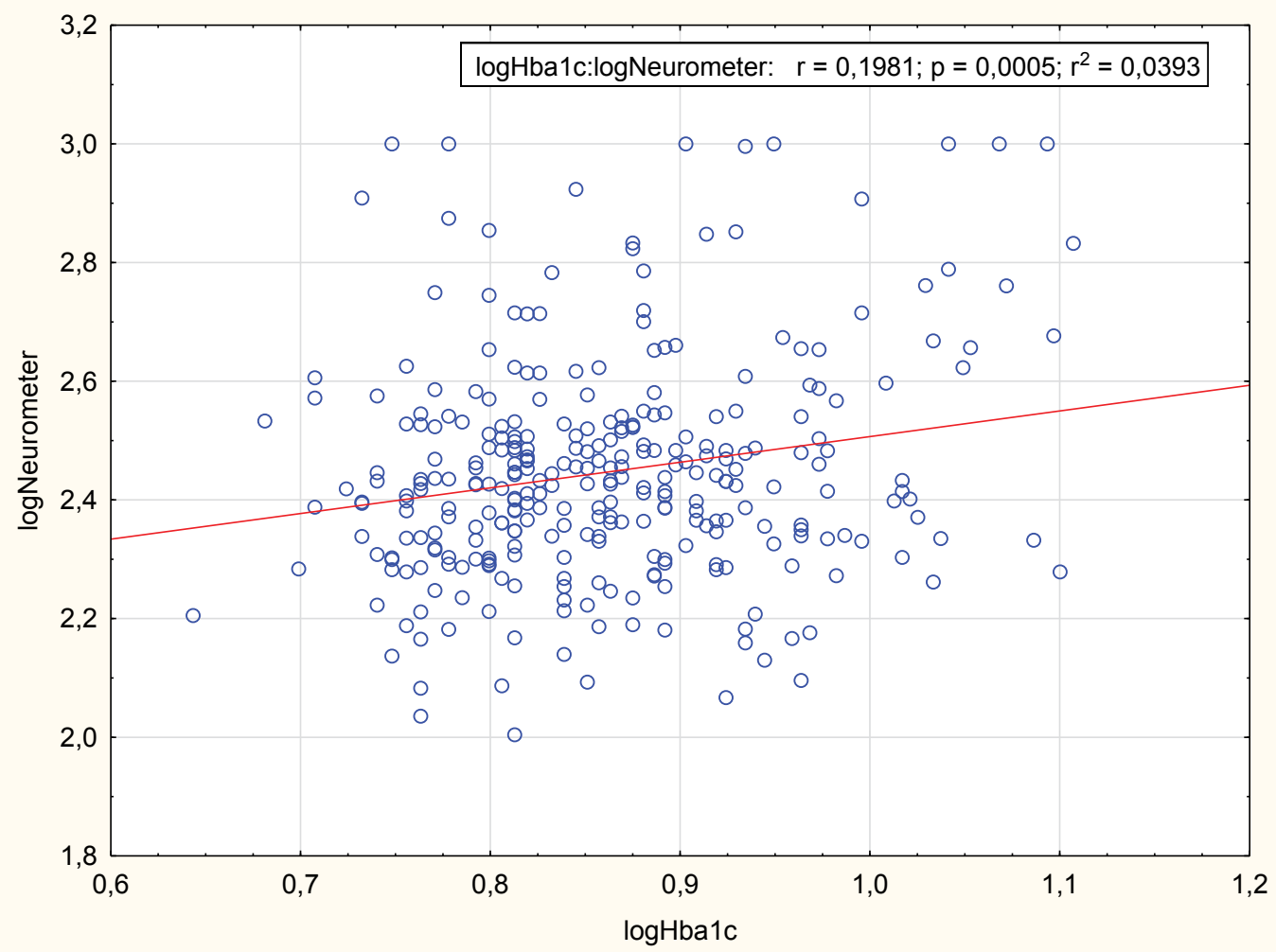

\begin{tabular}{l|l} 
4. ábra & $\begin{array}{l}\mathrm{A} \text { Neurometer } \\
\mathrm{HbA}_{\mathrm{lc}}=\text { hegítségével meghatározott áramérzet-küszöbérték átlagával jellemzett neuropathiás károsodás súlyossága és a HbA } \mathrm{A}_{\mathrm{lc}}\end{array}$
\end{tabular}

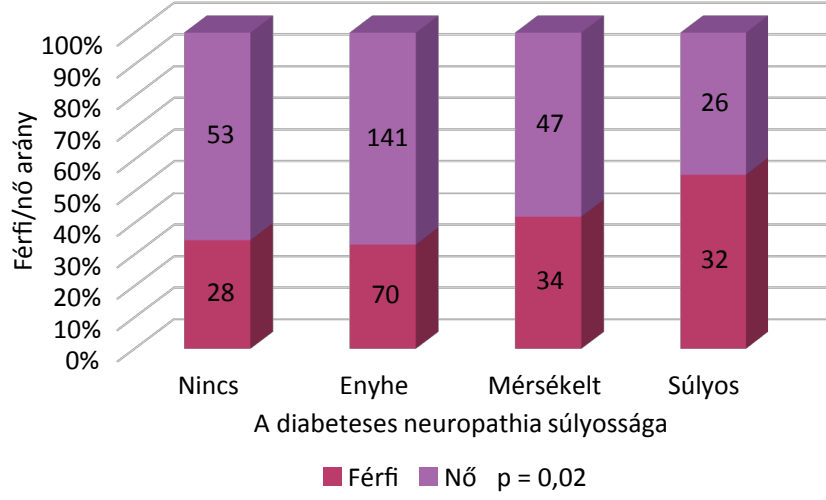

5. ábra

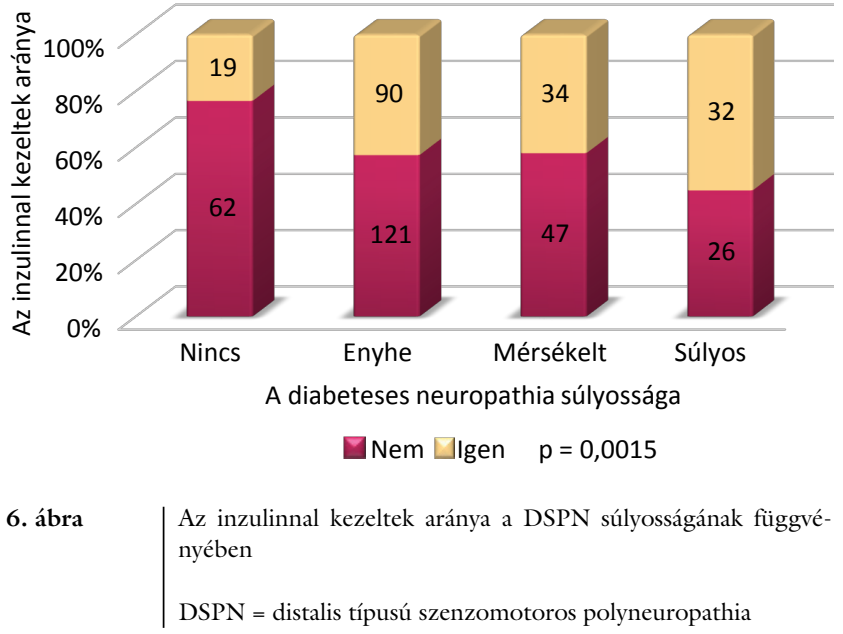

ressziós analízist végezve azt találtuk, hogy mind férfiak $(\mathrm{r}=0,21, \mathrm{p}<0,05 ;$ nincs ábrázolva $)$, mind nők $(\mathrm{r}=0,26$, $\mathrm{p}<0,001$; nincs ábrázolva) esetében szignifikáns pozitív összefüggést mutat a cukorbetegség tartama a neuropathia súlyosságával. Vizsgálatunkban alcsoportelemzés során a HDL-szint szignifikánsan magasabbnak bizonyult a nóbetegek körében $\left(\mathrm{HDL}_{\mathrm{nó}}\right.$ : $1,42 \pm 0,44$ mmol/l; $\mathrm{HDL}_{\text {ffi }}: 1,19 \pm 0,35 \mathrm{mmol} / \mathrm{l}, \mathrm{p}<0,0001$; nincs ábrázolva). 
a)

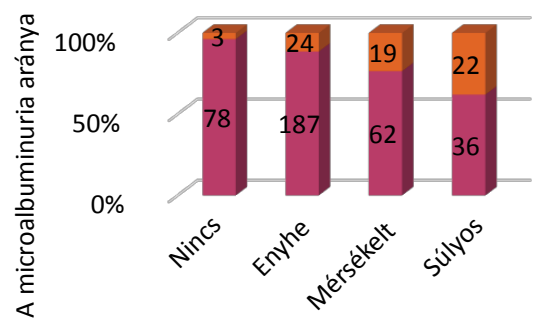

A diabeteses neuropathia súlyossága

Nem Igen $\quad p<0,0001$ b)

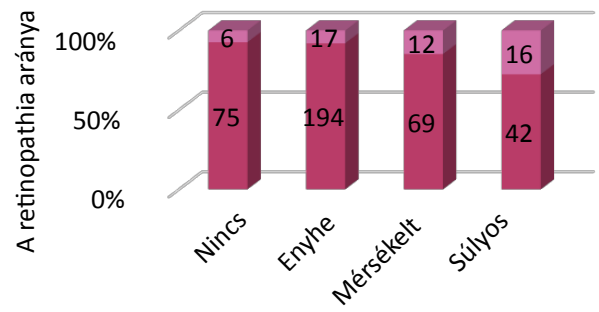

A diabeteses neuropathia súlyossága

Nem Igen $p=0,00029$

7. ábra

A microvascularis szövődmények (microalbuminuria [a]; retinopathia [b]) kapcsolata a DSPN súlyosságával

DSPN = distalis típusú szenzomotoros polyneuropathia

a)

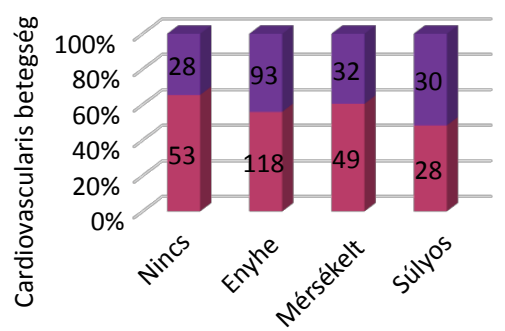

A diabeteses neuropathia súlyossága

Nem

$p=0,20$ b)

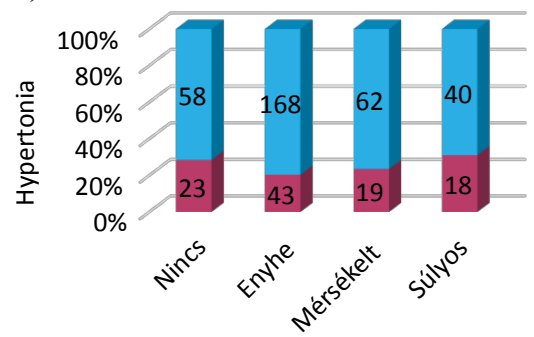

A diabeteses neuropathia súlyossága

Nem Igen $p=0,26$

8. ábra

A cardiovascularis szövődmények (a) és a hypertonia (b) jelenlétének összefüggései a DSPN súlyosságával

DSPN = distalis típusú szenzomotoros polyneuropathia

\section{Megbeszélés}

Vizsgálatunk során a microvascularis és CVD-szövődmények, illetve egyéb rizikófaktorok elöfordulását és az ezekkel kapcsolatos összefüggéseket elemeztük a Debreceni Egyetem Neuropathia Centrumában gondozott betegek adatai alapján. A cukorbetegség legkorábban és legjobban szürhető szövődménye a DSPN, azonban ennek ellenére jelentősen aluldiagnosztizált állapot. A microvascularis szövődmények (retinopathia, microalbuminuria) esetén súlyosabb neuropathiás károsodást találtunk, valamint a microvascularis szövődmények gyakrabban fordulnak elő a DSPN súlyosságának függvényében, ahogy ezt a nemzetközi irodalomban korábban már leírták [18]. Az általunk kimutatott eltérések egyenes arányú összefüggésben álltak az áramérzet-küszöbérték változásával, tehát a Neurometer ${ }^{\circledR}$-rel történő neuropathiás károsodás meghatározása és annak követése alkalmas lehet a többi microvascularis szövődmény előrejelzésére is. Korábbi irodalmi adatok is arra utalnak, hogy a nephropathia és a retinopathia kialakulása szorosan összefügg súlyosabb DSPN-tüneteket mutató egyének esetén [19, 20]. Adataink elemzése során az összevontan kezelt CVD-szövődmények nem mutattak összefüggést a DSPN súlyosságával. Ennek hátterében feltehetően vizsgálatunk korlátai állhatnak. A szív- és érrendszeri betegségeket nem tudtuk külön elemezni keresztmetszeti és obszervációs jellegú adatelemzésünk során, mivel a rendelkezésre álló, sokszor hiányos kórelőzményi adatok és a változatos, BNO szerinti kódolás alapján megfelelő esetszámú, egységes alcsoportokat nem tudtunk alkotni. A microvascularis szövődmények (diabeteses retinopathia és nephropathia) vizsgálata szintén a kórelőzményi adatok alapján történt; az eltérô vizsgálati módszerek foóleg a diabeteses nephropathia esetén jelenthettek limitációt, mivel sokszor nem volt elemezhető, hogy az albuminuria jelenléte (kóros microalbuminuria-eredmény a laborokban vagy kóros albumin/kreatinin hányados) egyszeri vagy konstans tényező-e. Mind a microvascularis, mint a CVD-szövődmények és a diabeteses neuropathia kapcsolatának elemzésére további prospektív vizsgálatok, akár több magyarországi régiót magukban foglaló, multicentrikus adatok elemzése bővítheti ismereteinket. Munkánk során nem vizsgáltuk a diabeteses autonóm neuropathia összefüggését az egyéb szövődményekkel; a Ewing-féle cardiovascularis reflextesztek eredményével való összehasonlítás további információkat nyújthat a macrovascularis szövődmények és a DSPN súlyosságának kapcsolatáról. Keresztmetszeti jellegéből adódóan mortalitási adatok elemzésére vizsgálatunk nem terjedt ki. 
Számos tényezőből adódhat, hogy a dohányzással kapcsolatban nem találtunk szignifikáns összefüggést a diabeteses neuropathia súlyosságával. A dohányzás okozta károsodás multifaktoriális: nemcsak idegkárosodást, de angiopathiát is okoz, valamint a dohányosok hypoxiatürő képessége is fokozottabb, ami befolyásolhatja az áramérzet-küszöbérték meghatározását [20]. Az alkohollal kapcsolatosan a korreláció hiányát a gondos beválasztási kritériumok befolyásolhatták. Az alkoholfogyasztásról a betegek anamnézise alapján tájékozódtunk, a májenzimértékek alapján az egyértelmú alkoholos májkárosodást és az esetleges alkoholos eredetű neuropathiás eseteket kizártuk. A magas vérnyomás nemzetközi összehasonlításban sem mutatott összefüggést a DSPNnel 2-es típusú cukorbetegek esetén [21].

Eredményeink alapján a súlyosabb fokú neuropathiában szenvedő betegek körében férfidominancia volt megfigyelhető, ami már korábban is ismert volt a szakirodalomban. A férfiakban a cukorbetegség korábbi stádiumában és súlyosabb formában jelentkezik ez a microvascularis idegi szövődmény [22]. Egyrészt a férfiak nagyobb átlagmagassága és a perifériás idegrostok hossza összefüggésben állhat a súlyosabb fokú neuropathiás károsodással. Másrészt a metabolikus faktorok közül a cukorbetegségre jellemző dyslipidaemia is befolyásolhatja a neuropathia mértékét. Experimentális egérkísérletek alapján a magasabb HDL-koleszterin-szintet protektív faktorként azonosították a nőstény egyedek esetén. A HDL-hez kötött enzimek (például paraoxonáz, mieloperoxidáz) antioxidáns szerepet töltenek be az oxidatív stressz károsító hatásával szemben, így késleltetve a DSPN megjelenését [23]. Vizsgálatunkban alcsoportelemzés során a HDL-szint szignifikánsan magasabbnak bizonyult a női betegek körében, ami alátámaszthatja ezt az experimentális megfigyelést.

Az inzulinnal kezelt betegek körében súlyosabb fokú neuropathia volt megfigyelhető. Irodalmi adatok alapján a hosszabb betegségtartam és az elégtelen szénhidrátanyagcsere együttesen állhat a súlyosabb neuropathiás károsodás hátterében az inzulinkezelésben részesülő cukorbetegek esetén. Az inzulinkezelés feltehetően legfeljebb neutrális hatású a neuropathia progressziójára. Továbbá az inzulin jól ismert gyulladáscsökkentő hatása akár protektív tényező is lehetne a progresszió lassítására [24].

\section{Következtetés}

Összefoglalásképpen azt mondhatjuk, hogy a diabeteses neuropathia szûrő jellegű vizsgálata kiemelt fontosságú a cukorbetegek körében. A diabeteses neuropathia centrumokban Neurometer ${ }^{\circledR}$ segítségével a DSPN progresszióját követhetjük, és ezzel előre jelezhetjük egyéb microvascularis szövődmények megjelenését is. A DSPN cardiovascularis betegségekkel való összefüggésének elemzésére további vizsgálatok szükségesek.
Anyagi támogatás: Munkánk a Magyar Diabetes Társaság 2019. évi klinikai kutatási pályázatának támogatásával készülhetett el. A publikáció elkészítését az EFOP3.6.2-16-2017-00009. számú projekt támogatta.

Szerzôi munkamegosztás: B. B. és Sz. F. a szakirodalmi adatok feldolgozásában, adatok gyüjtésében és értékelésében, T. N., Z. E. és J. A. Á. a kézirat szerkesztésében, M. Á. és P. Gy. a végső változat ellenőrzésében mưködött közre. A cikk végleges változatát valamennyi szerző elolvasta és jóváhagyta.

Érdekeltségek: A szerzőknek nincsenek érdekeltségeik.

\section{Irodalom}

[1] Zheng Y, Ley SH, Hu FB. Global aetiology and epidemiology of type 2 diabetes mellitus and its complications. Nat Rev Endocrinol. 2018; 14: 88-98.

[2] International Diabetes Federation. IDF Diabetes Atlas, 9th edition. IDF, Brussels, 2019. Available from: https://www.diabetesatlas.org.

[3] Kempler P, Putz Zs, Kiss Z, et al. Prevalence and financial burden of type 2 diabetes mellitus in Hungary between 2001-2014 results of the analysis of the National Health Insurance Fund database. [A 2-es típusú diabetes előfordulása és költségterheinek alakulása Magyarországon 2001-2014 között - az Országos Egészségbiztosítási Pénztár adatbázis-elemzésének eredményei.] Diabet Hung. 2016; 24: 177-188. [Hungarian]

[4] Tamayo T, Rosenbauer J, Wild SH, et al. Diabetes in Europe: an update. Diabetes Res Clin Pract. 2014; 103: 206-217.

[5] Winkler G, Kempler P. Pathomechanism of diabetic neuropathy: background of the pathogenesis-oriented therapy. [A neuropathia diabetica patomechanizmusa: az oki kezelés elméleti háttere.] Orv Hetil. 2010; 151: 971-981. [Hungarian]

[6] Pop-Busui R, Boulton AJ, Feldman EL, et al. Diabetic neuropathy: a position statement by the American Diabetes Association. Diabetes Care 2017; 40: 136-154.

[7] Brownrigg JR, Lusignan S, McGovern A, et al. Peripheral neuropathy and the risk of cardiovascular events in type 2 diabetes mellitus. Heart 2014; 100: 1837-1843.

[8] Kärvestedt L, Mårtensson E, Grill V, et al. Peripheral sensory neuropathy associates with micro- or macroangiopathy: results from a population-based study of type 2 diabetic patients in Sweden. Diabetes Care 2009; 32: 317-322.

[9] Brownlee M. Biochemistry and molecular cell biology of diabetic complications. Nature 2001; 414: 813-820.

[10] Cameron NE, Eaton SE, Cotter MA, et al. Vascular factors and metabolic interactions in the pathogenesis of diabetic neuropathy. Diabetologia 2001; 44: 1973-1988.

[11] Callaghan BC, Cheng HT, Stables CL, et al. Diabetic neuropathy: clinical manifestations and current treatments. Lancet Neurol. 2012; 11: 521-534.

[12] Hosseini A, Abdollahi M. Diabetic neuropathy and oxidative stress therapeutic perspectives. Oxid Med Cell Longev. 2013; 2013: 168039

[13] Sztanek F, M Molnár Á, Balogh Z. The role of oxidative stress in the development of diabetic neuropathy. [Az oxidatív stressz szerepe a diabeteses neuropathia kialakulásában.] Orv Hetil. 2016; 157: 1939-1946. [Hungarian]

[14] Schemmel KE, Padiyara RS, D'Souza JJ. Aldose reductase inhibitors in the treatment of diabetic peripheral neuropathy: a review. J Diabetes Compl. 2010; 24: 354-360.

[15] Du XL, Edelstein D, Rossetti L, et al. Hyperglycemia-induced mitochondrial superoxide overproduction activates the hexosamine pathway and induces plasminogen activator inhibitor- 1 
expression by increasing Spl glycosylation. Proc Natl Acad Sci USA 2000; 97: 12222-12226.

[16] Putz Zs, Hermányi Zs, Tóth N, et al. Testing distal sensory neuropathy in diabetes care. [A distalis típusú sensoros neuropathia diagnosztikája a diabetológiai gyakorlatban.] Diabet Hung. 2008; 16: 157-164. [Hungarian]

[17] Kempler P, Tesfaye S, Chaturvedi N, et al. Autonomic neuropathy is associated with increased cardiovascular risk factors: the EURODIAB IDDM complications study. Diabet Med. 2002; 19: 900-909

[18] Papanas N, Ziegler D. Risk factors and comorbidities in diabetic neuropathy: an update 2015. Rev Diabet Stud. 2015; 12: 48-62

[19] Dyck PJ, Kratz KM, Karnes JL, et al. The prevalence by staged severity of various types of diabetic neuropathy, retinopathy, and nephropathy in a population-based cohort: the Rochester Diabetic Neuropathy Study. Neurology 1993; 43: 817-824. [Correction: Neurology 1993; 43: 2345.]

[20] Tesfaye S, Chaturvedi N, Eaton SE, et al. Vascular risk factors and diabetic neuropathy. $\mathrm{N}$ Engl J Med. 2005; 352: 341-350.
[21] Grisold A, Callaghan BC, Feldman EL. Mediators of diabetic neuropathy: is hyperglycemia the only culprit? Curr Opin Endocrinol Diabetes Obes. 2017; 24: 103-111.

[22] Aaberg ML, Burch DM, Hud ZR, et al. Gender differences in the onset of diabetic neuropathy. J Diab Compl. 2008; 22: 8387.

[23] O'Brien PD, Hur J, Robell NJ, et al. Gender-specific differences in diabetic neuropathy in BTBR ob/ob mice. J Diab Compl. 2016; 30: 30-37.

[24] Sun Q, Li J, Gao F. New insights into insulin: the anti-inflammatory effect and its clinical relevance. World J Diabetes 2014; 5 : $89-96$.

\title{
MEGHÍVó
}

\section{Romhányi Orvostalálkozó - Lelkigyakorlat (manréza) orvosoknak Szár, Római katolikus templom - 2020. szeptember 5 .}

\author{
Moderátor: Prof. Dr. Szelényi Zoltán
}

\section{Fontos információk}

Részvételi szándék 2020. augusztus 20-ig naponta 14-16 óra között Koltayné Bartha Magdánál jelezhető. Telefon: 06-20/960 5854 - e-mail: baratikor.saar@gmail.com

Az Orvostalálkozók eddig döntően a résztvevők áldozatos adományaiból valósultak meg. Kérjük, hogy lehetősége szerint ebben az évben is támogassa rendezvényünket a Szár Községért Baráti Kör részére (UniCredit Bank 10918001-00000036-60180000) átutalható vagy a helyszínen kapható csekken befizetett összeggel, Romhányi Orvostalálkozó megjegyzéssel.

\section{Program:}

900 Szentmise

$10^{00}$ Üdvözlések Németh Norbert, polgármester Prof. Dr. Kellermayer Miklós: „Húsz év”

$10^{30}$ Márfi Gyula (nyugalmazott veszprémi érsek): „Gondolatok Európa jövőjéröl”

$11^{00}$ Avanesian Alex (dramaturg, szerkesztő, rendezö): „Kőország”

$11^{30}$ Lehoczky László (rendező, szerkesztő): „A szeretet a legnagyobb! - gondolatok a média hivatásáról"

$14^{00}$ Prof. Dr. Kellermayer Miklós, Prof. Dr. Sándor Zoltán: „A molekuláktól a komplex rendszerekig”

$14^{30}$ Prof. Dr. Cziráki Attila: „A kardiológia új dimenziói”

$15^{00}$ Prof. Dr. Pár Alajos: „Haladás a vírushepatitiszek prevenciójában és gyógyításában”

$15^{30}$ Prof. Dr. Than Péter: „Innovatív endoprotetika”

A cikk a Creative Commons Attribution 4.0 International License (https://creativecommons.org/licenses/by/4.0/) feltételei szerint publikált Open Access közlemény, melynek szellemében a cikk bármilyen médiumban szabadon felhasználható, megosztható és újraközölhetö, feltéve, hogy az eredeti szerző és a közlés helye, illetve a CC License linkje és az esetlegesen végrehajtott módosítások feltüntetésre kerülnek. (SID_1) 